\title{
Vuollerim
}

\section{Six Thousand and Fifteen Years Ago}

\author{
David Loeffler
}

\begin{abstract}
The theoretical background that led to the discovery and excavation of the Late Mesolithic semi-subterranean dwelling at Vuollerim is presented. This is followed by an interpretation of the social function of the house. A comparison with contemporary dwellings is made and the cultural context of the Vuollerim site is explored. The paper ends with some observations and thoughts concerning the impact that the archaeological discovery in Vuollerim had on its present day inhabitants and how it changed their view of themselves, their history and their future.
\end{abstract}

David Loeffler. Department of Archaeology and Saami Studies, Umea University, SE-901 87 Umeà, Sweden.

\section{INTRODUCTION}

In my opinion, one of the most exciting results of the Lule River Interdisciplinary Research Project was the discovery of a Late Mesolithic dwelling at Vuollerim in the Parish of Jokkmokk in northern Sweden. The site was discovered 15 years ago and the excavation of the house (commonly known as Norpan 2) was completed 11 years ago. Only a few publications have been written since then and there has been no overall presentation of the excavation in English since 1985, or in Swedish since 1986 (Loeffler \& Westfal 1985 , 1986). It need hardly be mentioned that both of these papers were obsolete within six months of publication due to the ongoing excavations. The absence of any recently published material concerning this site has led to the somewhat embarrassing situation in which antiquated papers are still being cited by colleagues. It is my intention to partly rectify this deficiency by briefly presenting the essentials concerning the excavations carried out between 1983-1987, accompanied by a few observations on the similarities and dissimilarities with contemporary Mesolithic sites in northern Sweden (fig. 1). This is followed by a preliminary hypothesis concerning the social organization and settlement patterns that created the remains at Vuollerim and its cultural context. In conclusion, a commentary concerning the effects that the discovery has had in archaeology and on the historical awareness of the local community is presented.

I am not an empiricist. I am quite aware of the connections and dependencies between what we consider as facts and prevailing theories. I am convinced that our theories determine both what is chosen and not chosen as relevant, either explicitly or implicitly, in any given scientific situation. Despite this awareness I am not going to elaborate on the possible reasons behind what is presented here, nor the how's and why's behind the interpretation of the material. Let it be sufficient to say that I fully expect this paper to become redundant within the near future thanks to the continuing work on Vuollerim. 


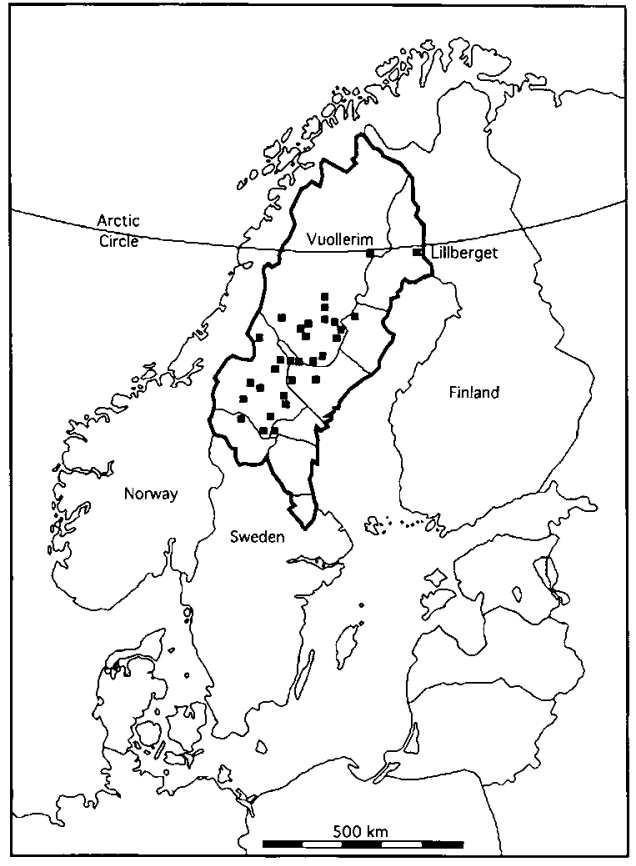

Fig. 1. The boundaries of Norrland are marked with a thick black line. Sites with one or more embankments of fire-cracked stone are represented by black squares. The Vuollerim and Lillberget sites lie near the Arctic Circle. East of Vuollerim and south of Lillberget there are a number of recently discovered but unexplored sites with the remains of houses from different periods which have not been included in this map.

\section{BACKGROUND}

The archaeological field surveys in and around the Parish of Jokkmokk were implemented to test a theoretical framework which basically consisted of two parts, a socioeconomic and a ecological component. The socio-economic component was summarised in four hypothetical models (fig. 2). These four models were first presented by Forsberg and Westfal in a temporary exhibition at the County Museum in Jokkmokk in 1983. The models predict that the economic and social structure of prehistoric societies in this area had undergone changes and, more or less, evolved in four stages.
The ecological component of the model presumed that the hunter-gatherer groups would try to maximize their efforts by exploiting those environments which contained many diversified ecological niches within a relatively limited and well defined area. Environments containing rivers, streams, bogs, forests and lakes within a radius of 10 kilometers were considered as likely areas in which prehistoric societies would have situated their base camps.

The resulting archaeological survey was goal oriented. Its aim was to find and document prehistoric sites as specified by the theoretical models. Map studies were carried out with the theoretical concepts in mind and areas that seemed likely to fulfill the hypothetical requirements were targeted for archaeological survey.

The theoretical models said, among other things, that hunter-gathering societies should have moved within well defined territories and that they would have situated key sites in ecologically rich areas. If this were so, then one would expect, sooner or later, to find the remains of substantial structures that served as winter dwellings. Exactly what such a structure would look like was any one's guess. Ethnographic studies showed that the most common winter dwelling in circumpolar areas was the subterranean or semi-subterranean dwelling. The work that was then being carried out on embankments of firecracked stone in central Norrland by Åsa Lundberg and Lars-Göran Spång was well known. They proposed that the embankments of fire-cracked stone were the remains of semi-subterranean winter dwellings and they were undertaking excavations to gain support for this hypothesis. Embankments of firecracked stone had not been found in northern Norrland, but the general trend of Lundberg's and Spång's reasoning was in accord with that of Forsberg's and Westfal's. Thus the main focus of the archaeological survey in the Jokkmokk area was to discover the remains of semi-subterranean structures, 


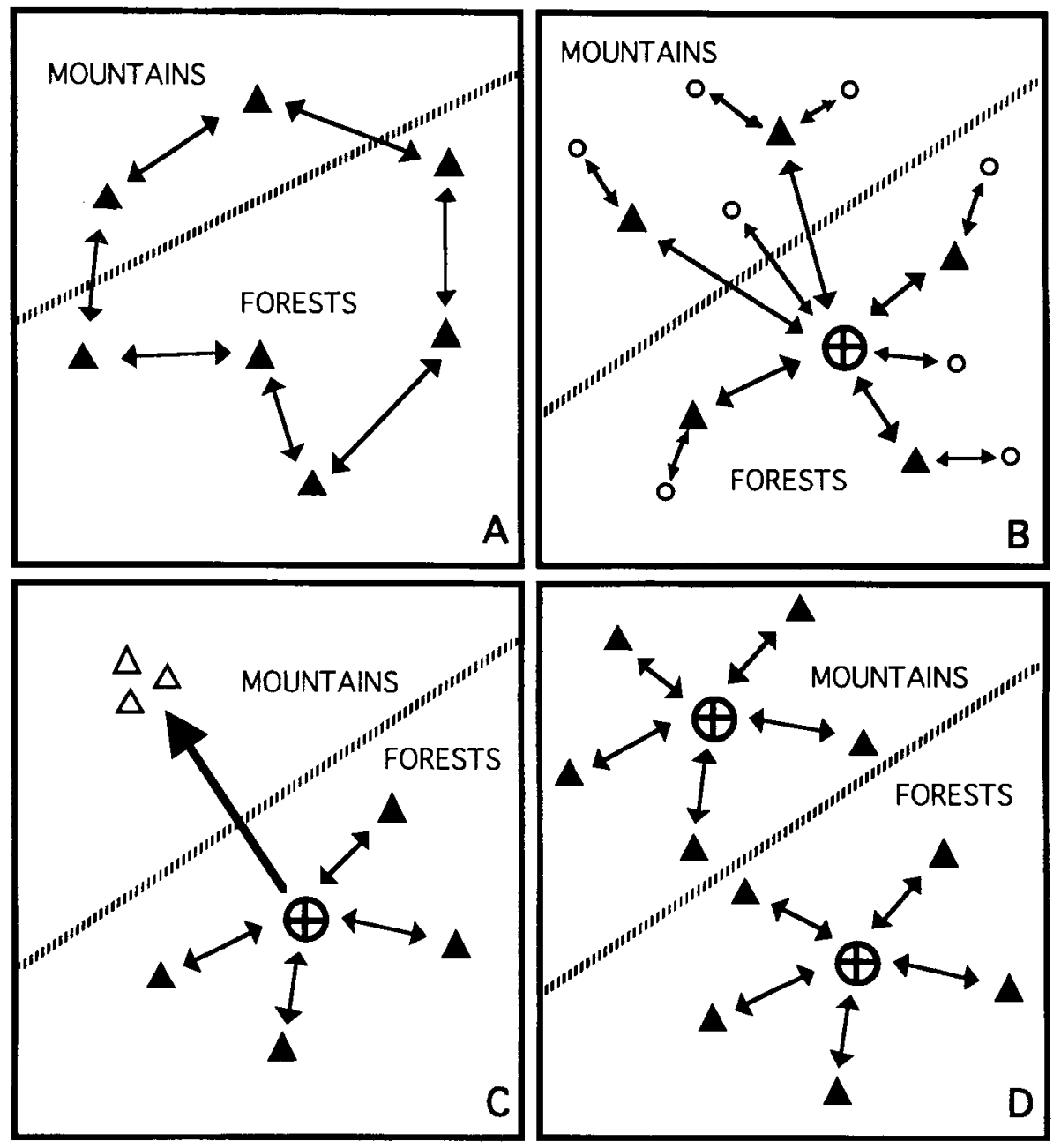

Fig. 2. Four hypothetical models that illustrate the four presumed settlement patterns that could have existed during different prehistoric periods in northern Norrland. The archaeological surveys in and around Jokkmokk parish in 1983 were carried out with the intention of finding and documenting sites that would confirm the models credibility. The simplified illustrations above were redrawn from photographs of the original drawings as they were presented in the 1983 exhibition.

A) 7000-4000 BC. Small sites inhabited by small groups of hunter-gatherers with a mobile lifestyle.

B) 4000-2000 BC. Larger sites in the forest areas with winter dwellings (base camps) occupied by a local group with seasonal movements to temporary sites and activity areas by segments of the local group.

C) 2000-500 BC. Larger sites in the forest areas with winter dwellings (base camps) with seasonal movements to temporary sites. Specialised hunting activities were carried out in the mountain areas on a seasonal basis.

D) 500 BC-500 AD. Sites grouped in distinct concentrations in the forest and mountain areas with empty areas between the different territories. 
despite the fact that we had no real idea about what they may have looked like.

The theoretical model was partly deterministic in character and was clearly a product of the processual school of archaeological thought which was dominant at that time. And despite all its drawbacks, it still produced astounding results.

\section{NORPAN 2 - THE BARE ESSENTIALS}

The site (Raä 1292) is situated 13 kilometers south of the Arctic Circle between the Stora and Lilla Lule Rivers, 1 kilometer west of their confluence, in a pine forest punctuated by peat bog deposits (fig. 12). Four houses and numerous other traces of prehistoric activity cover an area of approximately $500 \times 300$ meters.

The excavated house, Norpan 2, appeared as a shallow oval depression, 12 meters long (E-W), 5-6 meters wide (N-S) and 25-35 centimeters deep. Immediately adjacent to and SW of the house was a round shallow depression, 2 meters in diameter and 5-10 centimeters deep that was at first considered to be a result of a tree fall but which would prove to be the remains of one of two tent like structures.

The excavations revealed a rectangular floor, 10.7-12 meters long and 4.2-4.7 meters wide. In and around this floor were a number of different features, such as cooking pits and hearths as well as two other floor areas (see fig. 3). The archaeological remains consisted of fire-cracked stones, tools and flakes, primarily of quartz with minor amounts of quartzite, flint, slate, greenstone (Sw. strålstensskiffer) and hälleflinta, burnt and unburnt bones as well as red ocher.

\section{THE ARRANGEMENT OF THE HOUSE}

The floor area of the house is approximately

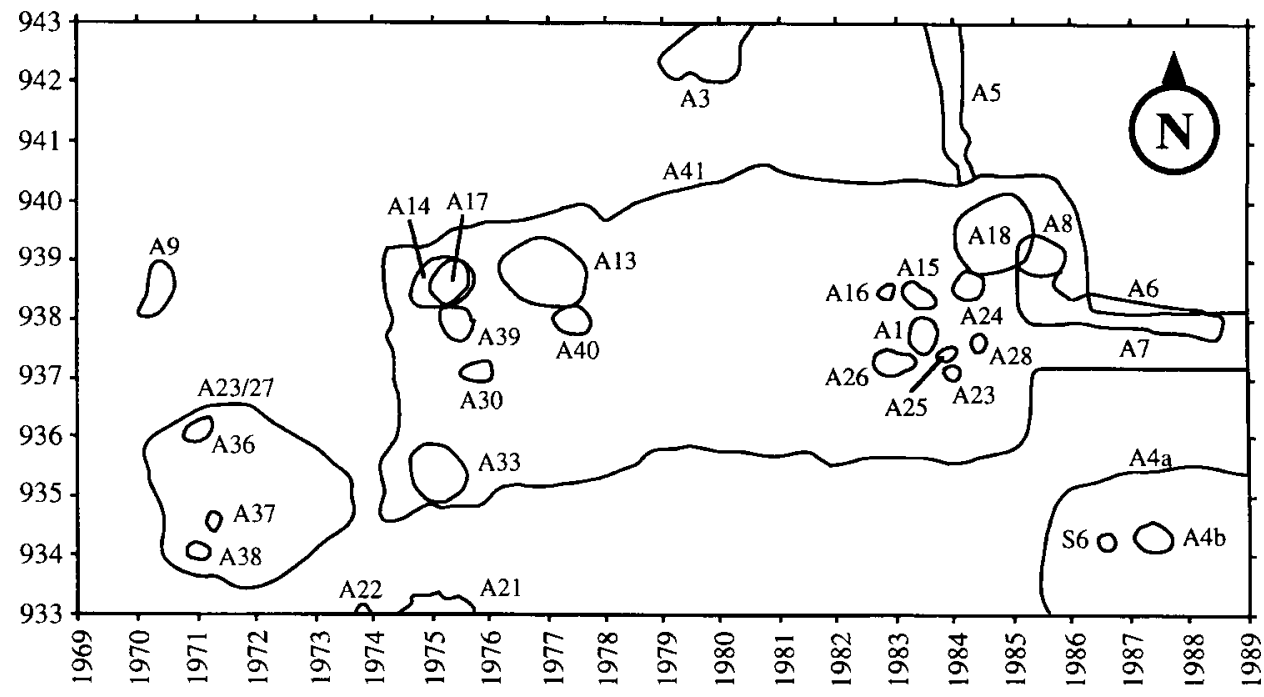

Fig. 3. The excavated area above is 200 square meters. The large rectangular house (A4I) in the middle was 10.7-12 meters long and 4.2-4.7 meters wide. Southwest and southeast of the large house were two floor areas, the remains of tent like constructions ( $A 4$ a and $A 23 / 27)$. Scattered both within and without these three floor areas were a number of other features, hearths $(A 4 b, A 8, A 9, A 15, A 16, A 24, A 26, A 28$, A30, A39 and A40), cooking pits (A1, A21, A22, A23 and A25), storage pits (A13, A14 and A33), postholes (S6, A37, A38 and A39), a rubbish pit (A3), an air shaft? (A5), a chimney (A6), an entrance tunnel? (A7), a wooden dish (A17) and a warming pit? (A18). The boundaries of the embankment that surrounded the large house and which, due to erosion, completely covered it and the other features, is not depicted. 


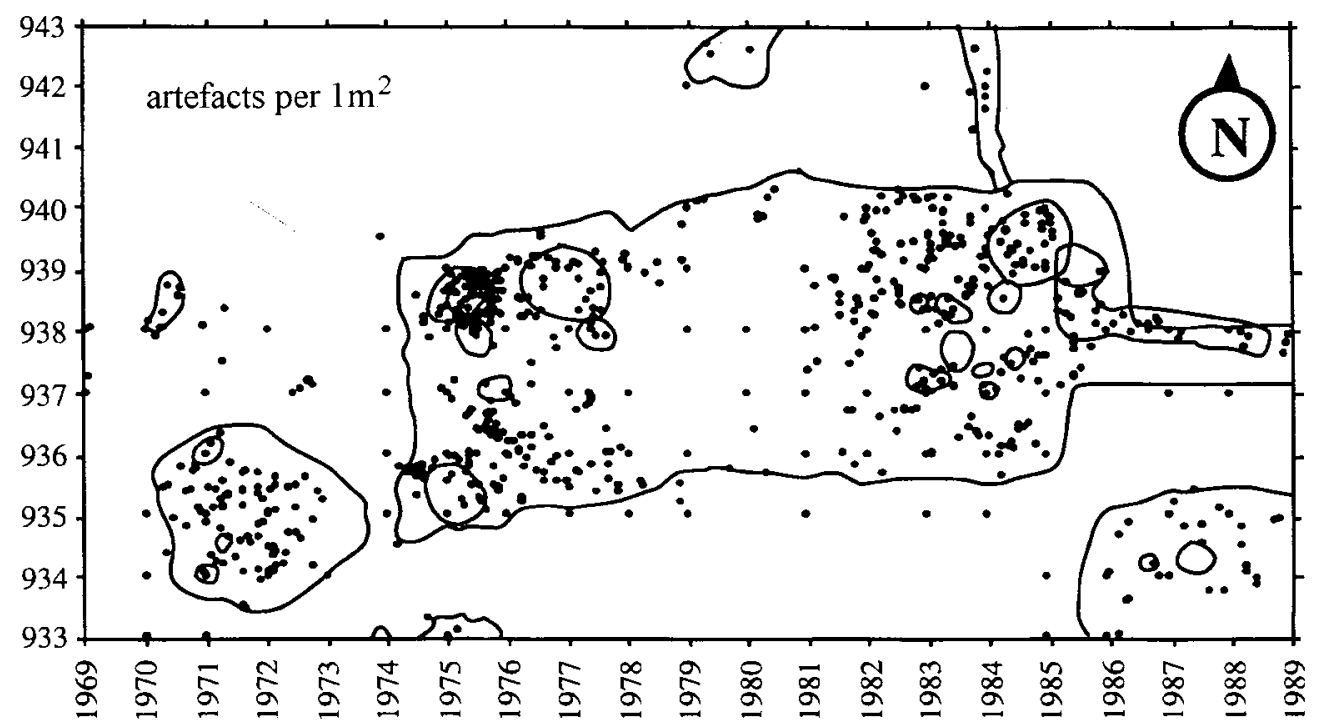

Fig. 4. Dot density map showing the distribution of the 1805 stone tools that were found on or in the 212 centimeters thick floor area of the large house as well as tools found in the tent like constructions, in features or on the original ground surface. The distribution pattern is bimodal, with two main concentrations on each side of the house. A total of 2783 stone tools were recovered of which quartz made up $87.4 \%$, greenstone $5.7 \%$, slate $2.6 \%$, quartzite $1.5 \%$, unidentified stone material $1.2 \%$, flint $0.6 \%$, hälleflinta $0.5 \%$ and sandstone $0.1 \%$.

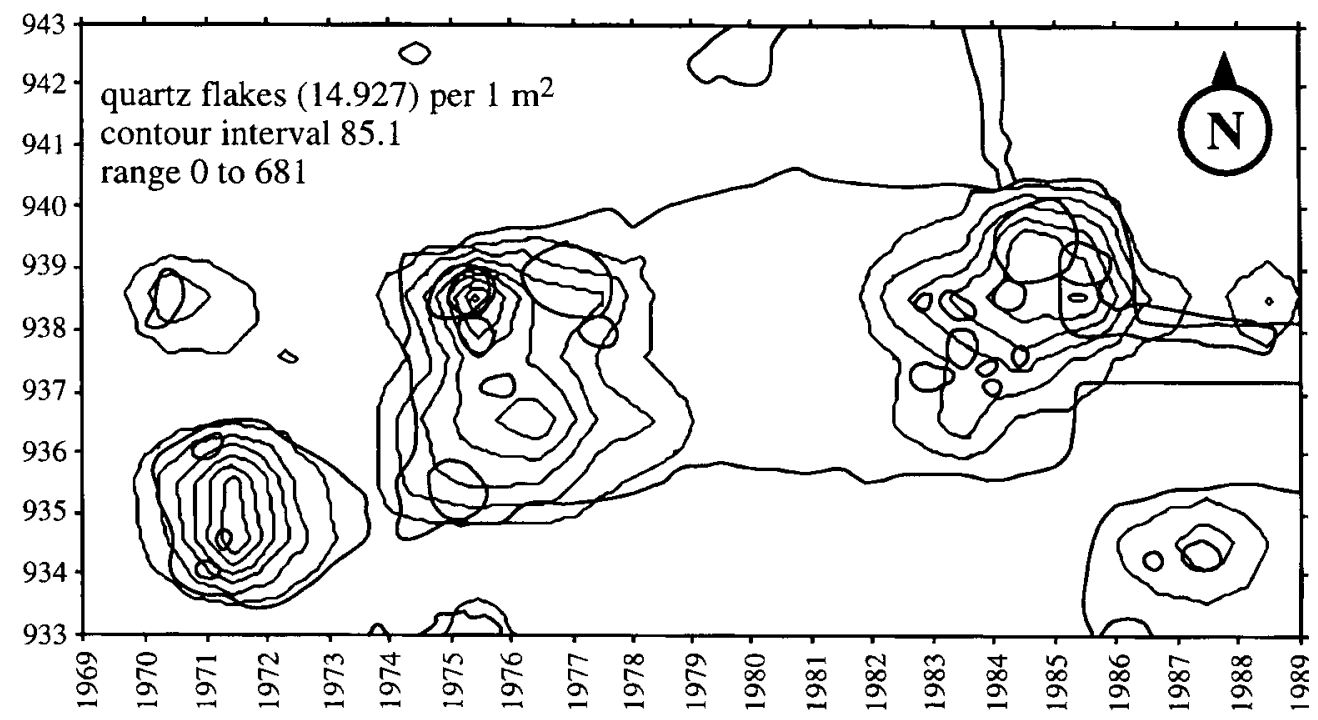

Fig. 5. Isometric map showing the distribution of the 14,927 quartz flakes that were found on or in one of the three floor areas, in features or on the original ground surface. The distribution pattern of this material is bimodal, with two main concentrations on each side of the house. A total of 36,952 flakes were recorded, 35,997 or $97.4 \%$ were of quartz. 


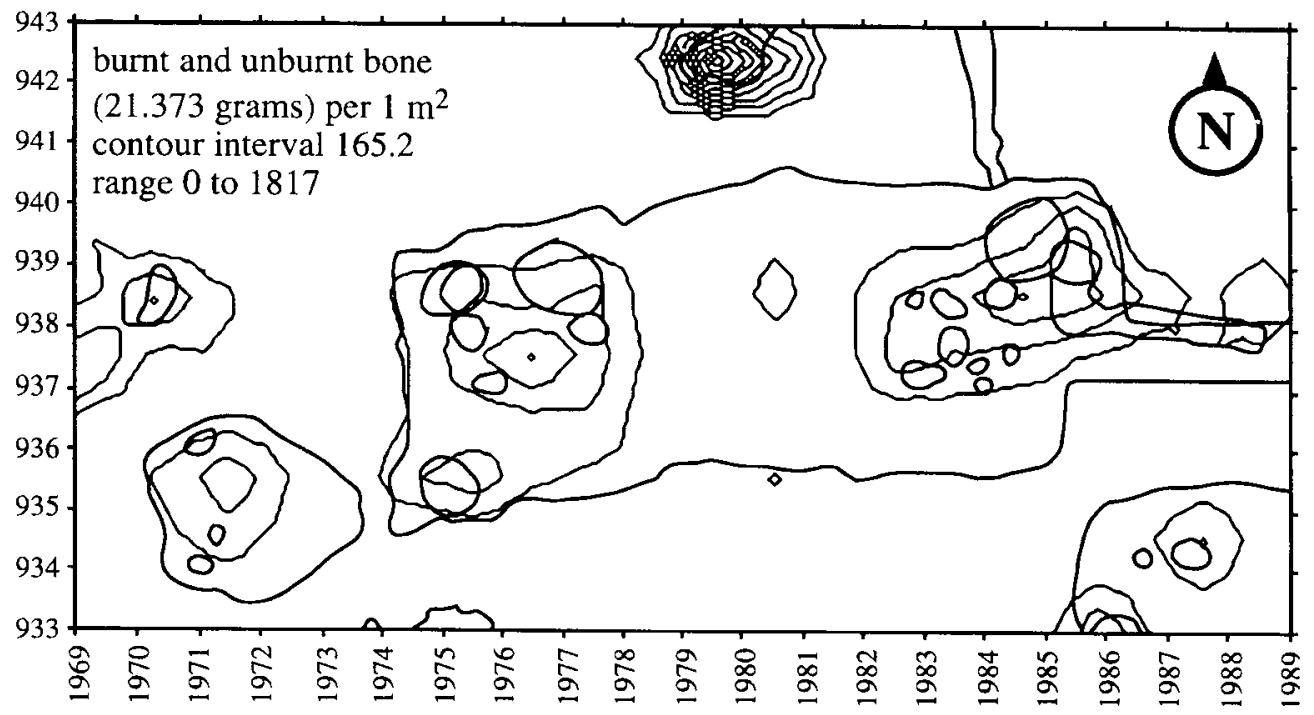

Fig. 6. Isometric map showing the distribution of the 21,373 grams of bone that were found on or in one of the three floor areas, in features or on the original ground surface. The distribution pattern of this material is bimodal, with two main concentrations on each side of the house. A third concentration is centred on and around the rubbish pit just north of the house. A total of 55,444 grams of burned and unburned bone were recovered. The large amount of bone recovered is unusual for sites in this part of the country. The preservation of the bone material is probably due to the fact that the lime content of the soil in this area is somewhat higher than normal for this part of the country.

$51 \mathrm{~m}^{2}$. Studies concerning the relationship between dwelling and household sizes of northern hunter-gatherers suggests that houses with a floor area exceeding $20 \mathrm{~m}^{2}$ were inhabited by more than one family (Helskog 1994; Lundberg 1997:100). This conclusion coincides with the bimodal pattern exhibited by the different material remains and, to a certain extent, the placement of the different features found within the boundaries of the main floor area.

The similarity between the distribution patterns of stone artefacts, quartz flakes, bone material, fire-cracked stones and red ocher is remarkable (see figs. 4-8.) They all exhibit bimodal concentrations, a distribution pattern which has been noted from other prehistoric houses and dwelling sites. This pattern may well indicate that two families inhabited the house and that each household utilized half of the dwelling (see discussion in Forsberg

\section{5:253ff, 1988:79ff).}

The distribution of quartzite flakes on the one hand and slate and greenstone flakes on the other exhibit a marked divergent pattern from that of the other materials (see figs. 910). The quartzite flakes are concentrated in the western half of the house and the slate and greenstone flakes are concentrated to the eastern half of the house. This pattern could be interpreted as reflecting a dual division of the household arrangements in that each respective family used the quartzite or the slate/greenstone material to underscore the division or differences between the two families. Needless to say, functional and gender aspects also need to be explored as possible alternative and/or complimentary explanations. A more detailed analysis of the patterning of the bone material and the phosphate record, together with the on going study of the distribution pattern exhibited by 


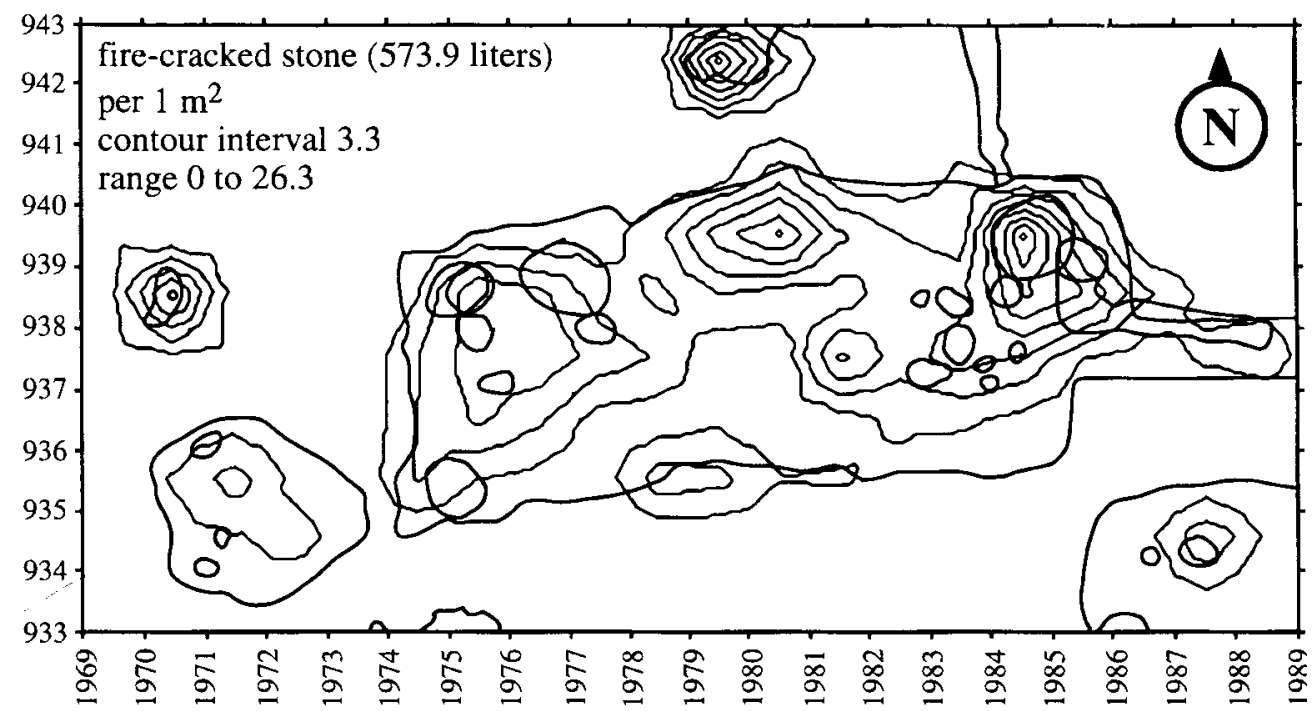

Fig. 7. Isometric map showing the distribution of the 573.9 liters of fire-cracked stone that were found on or in one of the three floor areas, in features or on the original ground surface. The distribution pattern of this material is more or less bimodal, with two main concentrations on each side of the house, with a third concentration situated along the north wall. A total of 1586.8 liters of fire-cracked stone were recorded.

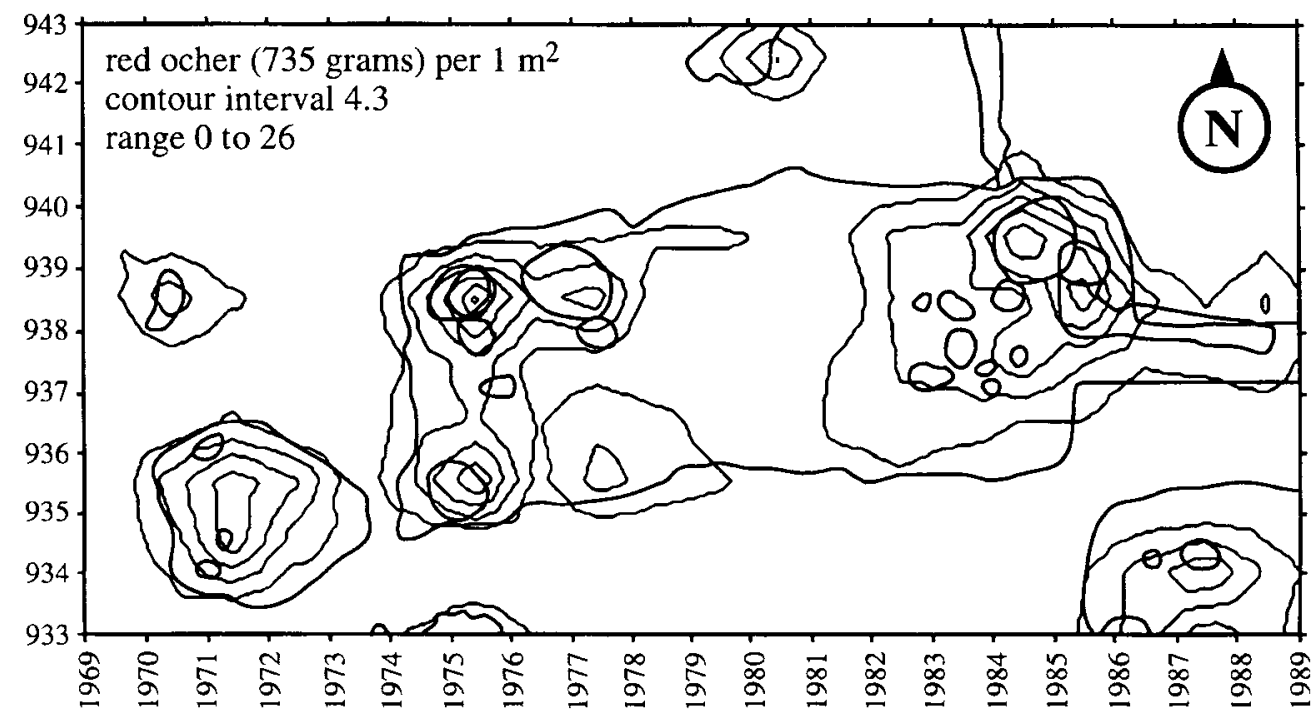

Fig. 8. Isometric map showing the distribution of the 735 grams of red ocher that were found on or in one of the three floor areas, in features or on the original ground surface. The distribution pattern of this material is again clearly bimodal, with two main concentrations on each side of the house and with a third concentration centered within the floor area of feature A23/27. Finds of red ocher often weighed much less than 1 gram and were therefore rounded upwards to the nearest whole number. 


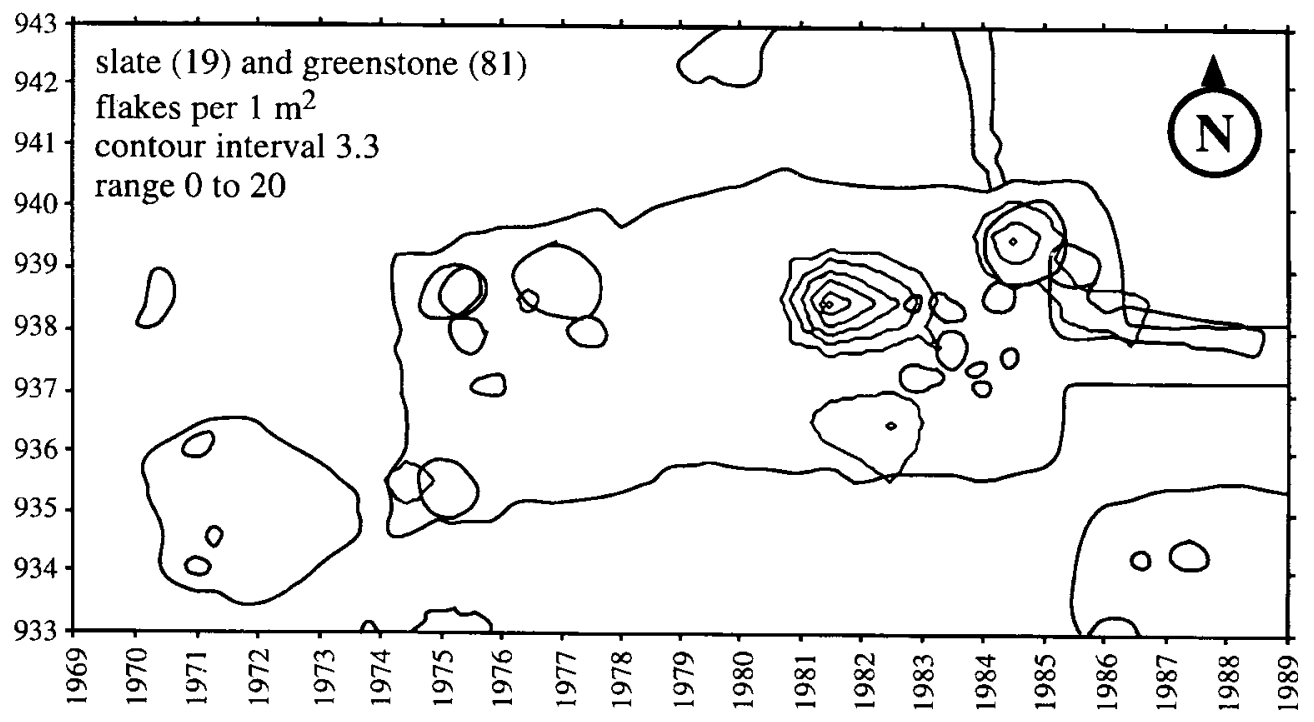

Fig. 9. Isometric map showing the distribution of the 100 slate and greenstone flakes that were found on or in one of the three floor areas, in features or on the original ground surface. The distribution pattern of this material shows two small but clear concentrations located in the eastern half of the house. A total of 33 slate and 171 greenstone flakes were recovered which together make up $0.55 \%$ of the total flake material.

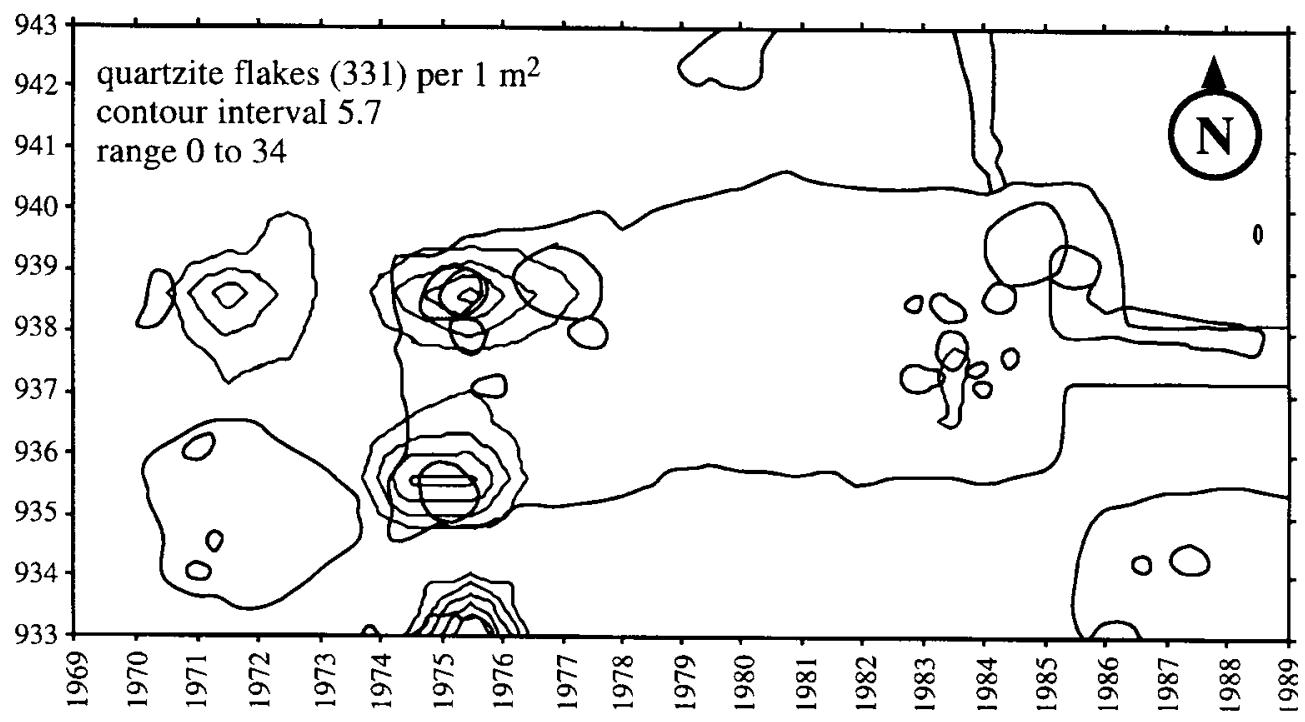

Fig. 10. Isometric map showing the distribution of the 331 quartzite flakes that were found on or in one of the three floor areas, in features or on the original ground surface. The distribution pattern of this material shows two small but clear concentrations located in the western half of the house and one south of the floor area in the vicinity of two presumed cooking pits, A21 and A22. A total of 715 quartzite flakes were recovered. They constitute $1.9 \%$ of the total flake material. 
the different tool types found within the floor area should throw new light on this problem.

(It should be noted that only the material remains that were found both on and in the floor areas, features and original ground surface have been utilized in creating the different distribution maps. All materials recovered from the embankment, which both surrounded and covered the floor areas and features, have been excluded from the analysis because they have undoubtedly been subjected to a certain amount of movement due to erosion.)

\section{FUNCTION OF THE HOUSE}

The house is interpreted as a winter dwelling. This interpretation is based on ethnographic parallels from northern areas where winter houses are often semi-subterranean (Lundberg 1997:94ff).

The house can also be interpreted as a base camp. A base camp can be defined using either social or economic criteria (Forsberg $1985,1988)$. There are two types of socially defined base camps. On the one hand there are small base camps which are inhabited by a local group consisting of 4-8 families which is the "...fundamental socio-economic unit of hunter-gatherers inhabiting the northern taiga areas..." (Forsberg 1988:59). The other type is the large base camp of the microband, which is made up of a number of local groups with a population of approximately 100 people.

There are also two types of economically defined base camps: semi-permanent and permanent. The semi-permanent base camps are occupied seasonally. Societies thus organized have at least two or more semipermanent base camps which are located in resource rich environments. People move between these different camps in order to utilize the different resources as they become available during different times of the year. Permanent base camps are also located in resource rich environments but these sites are more or less inhabited throughout the year.
Seasonally dictated movements from permanent base camps are only undertaken by parts of the population during the year. The size, duration and length of these movements is determined by the type of resource which is to be exploited.

Base camps of all types differ from other sites in that the archaeological remains on the former are more diverse and varied due to the fact that base camps are occupied over longer periods of time by larger numbers of people who are engaged in many different types of activities (Forsberg 1985, 1988).

The house in Vuollerim displayed a wide range of archaeological materials and remains. It is possible that the other three houses in the area were occupied at the same time and therefore together constitute the remains of a base camp for a local group. The features that have been interpreted as storage pits suggest that the house functioned as a permanent base camp in which seasonal resources were transported into the camp, rather than moving the total population to the seasonally available resources.

\section{FEATURE A4a AND A23/27}

During the excavation of the large semisubterranean house two other highly interesting features were uncovered which so far have never received any attention. Features A4a and A23/27 are two separate floor areas; the former was 4.5-5 meters long and 3.5-4 meters wide and rested directly on the original ground surface. The latter was $3.8 \times 3$ meters in diameter and 10-20 centimeters below the original ground surface. One cooking pit and one posthole were discovered within the boundaries of feature $\mathrm{A} 4 \mathrm{a}$ and three postholes were uncovered in feature A23/27. No cooking pit was found within feature $\mathrm{A} 23 / 27$ but one was discovered about 2 meters north of it.

These two features have been interpreted as the remains of two tent like constructions. Both contained tools, bones, fire-cracked stones, flakes and red ocher. 
Feature A23/27 differs radically from the other floor areas in that it contained abundant amounts of red ocher powder as did one of its postholes. The posthole in feature $\mathrm{A} 4 \mathrm{a}$ was similar in that it also contained a 2 centimeter thick bottom layer of red ocher. Otherwise, feature A4a did not contain noticeable amounts of red ocher.

Hunter-gatherers of Siberia and North America usually had both winter and summer houses. The thick earth and wooden walls and/or roof of the winter houses became uncomfortably damp during the summer which compelled its inhabitants to move into lighter and airier constructions (Lundberg 1997:95 plus references). This would be a plausible interpretation of these two tent like structures. But this does not explain the presence of the relatively high concentration of red ocher found within feature $A 23 / 27$.

This explanation assumes that the large house was contemporary with the tent constructions. Feature A4a was covered with soil from the embankment which surrounded the larger house, which implies that feature A4a is somewhat older. A radiocarbon date from the cooking pit in feature A4a gives some support to this assumption. The cooking pit was dated to $5575 \mathrm{BP}$ which means that it could belong to the beginning of the site's occupation. Feature A23/27 was partly covered by soil from the embankment of the larger house and partly by soil material from its own embankment, which would indicate that it was in use during the later phase of the site.

\section{EMBANKMENTS OF FIRE-CRACKED STONE AND VUOLLERIM}

In order to gain insight into the possible cultural context of the Vuollerim dwelling it is necessary to compare it with other contemporary houses. Åsa Lundberg has in a recent dissertation shown that the feature commonly known as embankments of fire-cracked stone (Sw. skärvstensvallar) are in fact the remains of semi-subterranean dwellings that were in use from the Late Mesolithic up until the end of the Neolithic (Lundberg 1997). A comparison between these inland dwellings and Vuollerim followed by a further comparison with the contemporary coastal dwellings at Lillberget in Överkalix parish, Norrbotten shows surprising similarities and differences.

The location of the Vuollerim house and its relationship to other features is similar to that of most embankments of fire-cracked stone. Embankments of fire-cracked stone are often located near the confluence of two water courses and are often placed 5-20 meters from the shore line (Lundberg 1997:102, 123). The four houses in Vuollerim at the time of their occupation were probably located in a delta like landscape near the confluence of the Lilla and Stora Lule Rivers between 5-20 meters from the water's edge.

The house at Vuollerim, like most embankments of fire-cracked stone, is located on gentle sloping sandy ground with good drainage properties.

Two to five embankments of fire-cracked stone are usually found together, with an internal distance of 100-500 meters between them. The distance between the four houses in Vuollerim is 60-180 meters.

Lundberg suggests that the presence of moose was taken into consideration when choosing a dwelling site. Most embankments of fire-cracked stone are found in conjunction with hunting pits (Lundberg 1997:123). There are a number of hunting pits in the vicinity of the Vuollerim site and one has been radiocarbon dated to $6315 \pm 315 \mathrm{BP}$.

There are also many similarities concerning the internal features found in and around the embankments of fire-cracked stone and the Vuollerim dwelling. The floor of the former is usually located $30-70$ centimeters below the surface of the ground. The floor of the Vuollerim house was situated 10-45 centimeters beneath the ground surface. The floor area of most embankments of firecracked stone is round, but oval and rectangular floor plans are also common. Half 
of the embankments of fire-cracked stone have a floor area of $5-20 \mathrm{~m}^{2}$ and the other half between $20-65 \mathrm{~m}^{2}$ with a concentration around 30-40 $\mathrm{m}^{2}$ (Lundberg 1997:103). Vuollerim's floor area is rectangular in shape and about $51 \mathrm{~m}^{2}$.

The greatest difference between Vuollerim and its contemporaries is the size of the embankment which surrounds the floor area. The latter is often both thicker and wider than that which surrounds the house at Vuollerim. As the name implies, embankments of firecracked stone are made up almost entirely of fire-cracked stones. This is in stark contrast to the embankment at Vuollerim which is mostly composed of sand. From one embankment in Vilhelmina the amount of firecracked stone for every excavated level of 10 centimeters per square meter was 50-100 liters (Lundberg 1997:50). In contrast, the embankment at Vuollerim produced on average 1-2.5 liters for every 10 centimeter per square meter.

The number of cooking pits and hearths in the floor area varies between 5-13 for the embankments of fire-cracked stone (Lundberg 1997:109). The cooking pits and hearths are often found grouped together near the center of the floor area or in close proximity of the entranceway. At Vuollerim, 8 of the 12 cooking pits and hearths in the floor area were found grouped together near what may have been the entranceway.

In both cases the shape and size of the cooking pits and hearths found inside and outside of the houses are almost identical: bowl shaped, between 40-70 centimeters in diameter and 30 centimeters deep (Lundberg 1997:108). And in both cases these features have not been in use simultaneously but were utilized, abandoned and cleared out at different times.

Features that have been interpreted as storage pits have been found on sites with embankments of fire-cracked stone and at Vuollerim. But while the three storage pits at Vuollerim were located within the house itself those found on sites with embankments of fire-cracked stone were placed outside of the dwellings (Lundberg 1997:110).

In both cases quartz is by far the most common raw material. It is accompanied by varying, though often minor amounts of quartzite, flint, slate, greenstone, hälleflinta and sandstone. Scrapers are the dominate tool type on sites with embankments of firecracked stone where they make up 54-99\% of the tools (Lundberg 1997:111). Scrapers make up only $40 \%$ of the tools at Vuollerim, followed by retouched flakes, $30 \%$, and cores, $12 \%$. Other tool types common to both embankments of fire-cracked stone and Vuollerim are polished tools of slate and greenstone.

The amount of burnt and unburnt bone recovered at Vuollerim, about 55 kilograms, surpasses that which is usually found elsewhere in Norrland. A proper osteological analysis has not yet been undertaken. The limited work that has been done shows that the material contains bones of moose, beaver, fish and birds, an assemblage which is typical of that which has been recovered from embankments of fire-cracked stone.

The flake material from Vuollerim also surpasses that which is usually recovered from embankments of fire-cracked stone. From the former 36,952 flakes were recorded. This is in stark contrast to the 2000-8000 flakes which are usually recovered from embankments of fire-cracked stone, with the exception of Bellsås in Tåsjö parish, Jämtland where 25,197 flakes were recorded (Lundberg 1997:26ff). Lundberg points out that this difference is probably the result of how accessible quartz was in relation to the sites. In the case of Vuollerim there is a quartz quarry 10 kilometers upstream from the site which was presumably in use at this time (Falk 1995).

Lundberg calculates that embankments of fire-cracked stone were inhabited between 500-1600 years and that a house construction itself was rebuilt every 30-70 years (Lundberg 


\begin{tabular}{lllllll}
\hline analysis no. & St 9647 & St 9648 & St 10515 & St 10516 & St 10517 & St 11616 \\
\hline feature & A 4b & A 3 & A 13 & A 6 & A 18 & A 33 \\
& hearth & $\begin{array}{l}\text { rubbish pit } \\
\text { storage pit } \\
\text { chimney }\end{array}$ & $\begin{array}{l}\text { warming pit } \\
\text { storage pit }\end{array}$ \\
sample no. & $4: 1983$ & $2: 1983$ & $30: 1985$ & $35: 1985$ & $37: 1985$ & $54: 1986$ \\
age BP & $5575 \pm 145$ & $5025 \pm 180$ & $4390 \pm 300$ & $5290 \pm 160$ & $5350 \pm 145$ & $5470 \pm 210$ \\
\hline
\end{tabular}

Fig. 11. Radiocarbon dates from Norpan 2 (J106A), Vuollerim, Rä̈ 1292, Jokkmokk's parish, Lappland. A half life of $5568 \pm 30$ was used. Analysis conducted by the Stockholm Radiocarbon Laboratory at the National Museum of Natural History (Sw. Naturhistoriska Riksmuseet).

1997:121). The ${ }^{14} \mathrm{C}$ dates from the large house at Vuollerim cover a 900 year period, from 5470-4390 BP.

The number of artefacts from Vuollerim and those from embankments of fire-cracked stone are similar. The large amounts of bone and flakes at Vuollerim could be the result of an occupation that is comparable in duration to that of embankments of fire-cracked stone. On the other hand the large amounts of bone at Vuollerim may solely be the result of preservation factors and the numerous quartz flakes a consequence of the accessibility of the raw material.

Two factors indicate a shorter occupation of the house at Vuollerim. The relatively small amounts of fire-cracked stone and the high degree of preservation of the different features suggests that the house was short lived. It should be pointed out that the difference between the amounts of fire-cracked stone may only be a consequence of how the stones were utilized and thus do not represent occupational duration.

In contrast, the well preserved condition of the features in and around the house at Vuollerim in comparison with those recorded from embankments of fire-cracked stone indicates that the occupation of the former was relatively short. Not all the features recorded at Vuollerim were in use simultaneously; a number of them cross cut others, but never to the extent that they completely overlay or destroy earlier features. The arrangement of the features in the house leaves one with the impression that the floor area was utilized according to explicit organizational principles that were in force throughout its occupation.

It should be noted that the Vuollerim site as a whole, of which this house is a part, has not yet been studied and therefore its duration is unknown.

Soil maps and landscape studies based on aerial photographs show that the Quaternary deposits of this area are transversed by a number of ancient glaciofluvial and/or alluvial river beds from west to east. Pollen from Polygonum amphibium, a water plant which in this part of the country only grows in running water, was recovered from the peat bog deposit next to the site (Wallin 1986; Loeffler \& Westfal 1985:426). It seems that the Lilla Lule River has meandered through the easily eroded soils of the area and changed course several times during the past (see fig. 12). It is possible that the river changed its course during the time of the site's occupation, causing the site to be abandoned, and that the high quality of preservation and the apparent short duration of the site is a consequence of this event.

\section{LILLBERGET AND VUOLLERIM}

The Lillberget site, Raä 451, in Överkalix parish lies 11 kilometers northwest of Överkalix and $120 \mathrm{~km}$ east of Vuollerim. Lillberget is one of a number of similar sites that have recently been discovered in the coastal region (Baudou 1992:69). So far it is the only site of 
its kind that has been documented and presented through the vigorous efforts of Halén (1994). A comparison between Lillberget and Vuollerim shows some similarities but the differences are even more striking.

The Lillberget site lies on a gentle north slope composed of sand just above a bog. Today the site is situated between 58-64 m.a.s.l. but at the time of occupation, 3900 $\mathrm{BC}$, it was located near the beach on a island at the bottom of a fjord like formation about 35 kilometers from the open sea.

The dwelling site consists of ten semisubterranean houses placed wall to wall in two groups. The floor area lies $40 \mathrm{~cm}$ beneath the surface of the ground and the houses are between 3.5-14 meters long and 3.5-9.6 meters wide (Halén 1994:83), a few being comparable in size to the house in Vuollerim.

Halén excavated three houses. Two hearths were found in each house, one on each side of the floor area. The hearths were rather large, being between 116-157 centimeters long and 57-124 centimeters wide (Halén 1994:86ff).

Quartz made up $79.5 \%$ of the stone material, followed by flint with $11.7 \%$ and greenstone, $7.6 \%$. The remaining $1.2 \%$ is made up of sandstone, slate, hälleflinta, quartzite and jasper. Ninety-four tools of quartz were recovered: 65 scrapers, 12 blades, 10 cores, 5 drills, 1 knife and 1 transverse

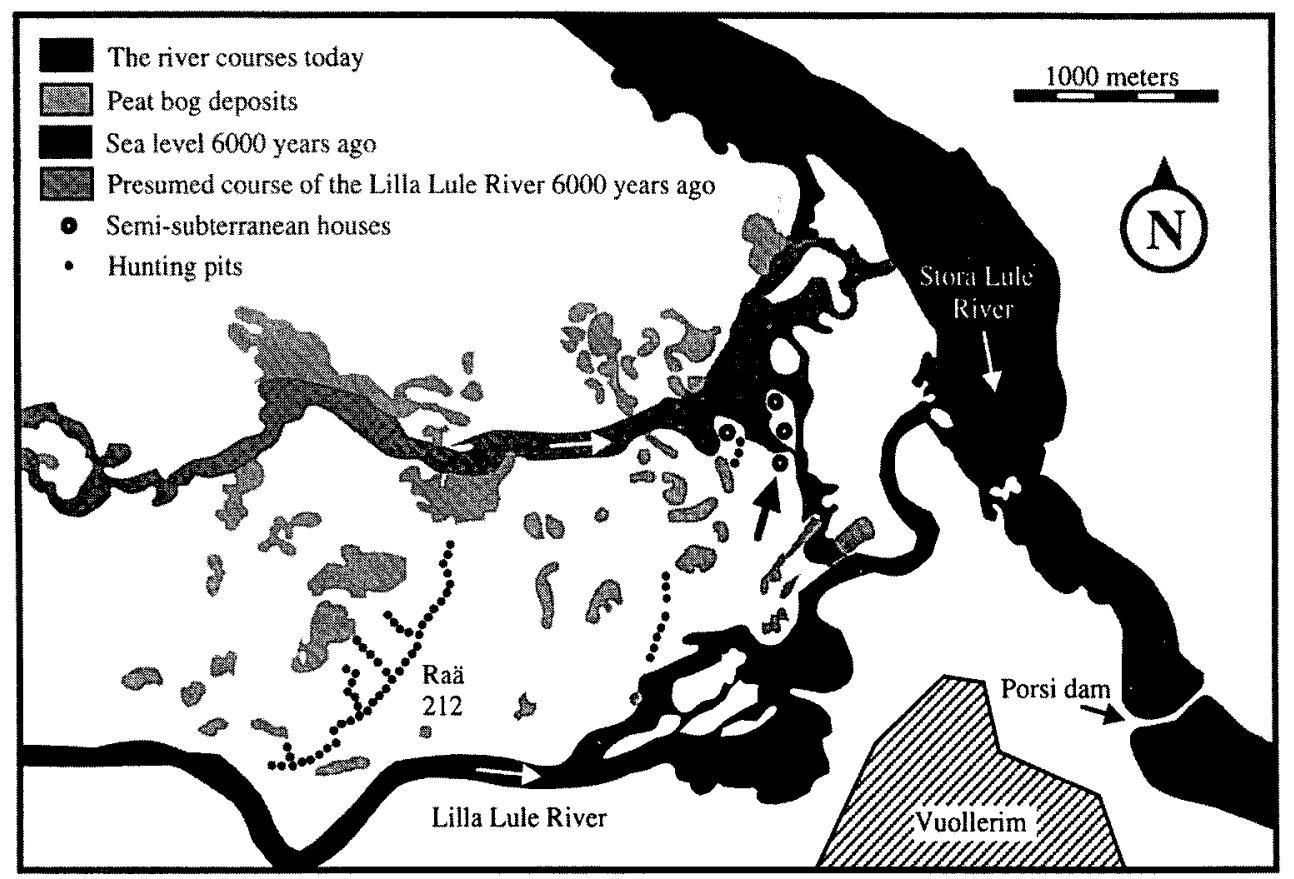

Fig. 12. The map shows the present watercourse of the Stora and Lilla Lule Rivers as well as the presumed watercourse of the Lilla Lule River during the time of the occupation of the site. Today the bed of this prehistoric watercourse has been transformed into bogland, covered over and/or destroyed through erosion. The four houses which are presumed to have originally been placed near the ancient river are today situated along the edges of peat bog deposits. During the time of occupation the Litorina Sea level was 60-70 meters higher than it is today. The open sea was situated 90 kilometers down stream and it could be reached from Vuollerim through the long fjord like inlet that stretched from the prehistoric coast right up to the present day location of the hydroelectric power plant at Porsi, about 2 kilometers SE of the site. The excavated house, Norpan 2, is marked with an arrow. 
arrow. Of the 69 tools made from flint there were 33 scrapers, 14 bifacial points, 13 blades and 2 transverse arrows. Nineteen tools of greenstone were recovered, 7 of these were axes or chisels and 4 were blades. Four scrapers and a number of flakes of red and green banded jasper were also found. Only one artefact of red slate was recovered, a small arrowhead with a wide tang and short straight barbs (Halén 1994:99ff).

Sixteen kilograms of Comb Ware ceramics and a bead of copper were also recovered from the Lillberget site (Halén 1994:128, 153).

Fire-cracked stones were found on the site but in such small amounts that their presence has only been noted in passing.

An analysis of the 2106 grams of bone that was recovered shows that $81.1 \%$ belong to different species of seal, $11.7 \%$ to moose or reindeer and $4.1 \%$ to beaver (Halén 1994:164).

Halén maintains that at least nine of the ten houses were inhabited at one and the same time with a population between $80-100$ people divided into 20 families. The site functioned as a permanent base camp which was in use throughout the year for a period of between 17-33 years (Halén 1994:175ff).

There is a certain amount of similarity between Vuollerim and Lillberget. Both sites share certain topographical features. The size of the houses is in some cases identical. Quartz is the dominate stone material and scrapers are the most common tool type.

Thereafter, the differences loom larger than the similarities. The placing of the houses wall to wall, the relatively few hearths in each house, their large size, the lack of other types of features, the apparent and near total lack of fire-cracked stones, the relatively large amounts of tools made of flint and greenstone and the almost total lack of tools made from slate and quartzite, the dominance of seal bone with traces of reindeer, the ceramics, the copper bead, the transverse arrows and bifacial points and the short occupation period are all substantial differences between these two sites.

The presence of one flake of red jasper as well as the few flakes and five microblades of flint and possibly even the greenstone artefacts from Vuollerim could be the result of some form of contact with the Comb Ware complex along the coast of which Lillberget is a part. The single point of red slate with a wide tang and short straight barbs, of which a similar type was found at Vuollerim made of greenstone, could also be the outcome of some type of contact.

\section{VUOLLERIM'S CULTURAL CONTEXT}

In contrast to Lillberget, Vuollerim appears to have many more similarities with the embankments of fire-cracked stone. The same types and frequencies of the stone materials and tool types, the presumed composition of the bone remains, the topographical location of the sites, their relationship to other houses and other types of remains, the size of the houses, the types of features found in and around the houses and the size of these features are all particularly similar.

The overall impression and the preliminary conclusion of this synthesis is that the house at Vuollerim is a northern offshoot of a cultural tradition which had its center in central Norrland. The nearest embankment of fire-cracked stone is found along the banks of Lais River about 170 kilometers south-east of Vuollerim as the crow flies. This cultural tradition is distinguished by a technology based on quartz and slate with small amounts of greenstone accompanied by modest quantities of other imported stone materials, with settlements situated along the inland waterways and centered around permanent base camps arranged into small villages with sparsely placed houses, characterised by a pronounced inland economy based on moose hunting, fishing and beaver trapping and a social organisation built up around a local group with long distance but presumably limited contacts with other areas and groups 
of people.

This shared cultural tradition can be defined as a social territory with "...one or more related language groups which share a common material culture..." with social relations and contacts in the form of movement of both people through marriage and products (Lundberg 1997:131).

The similarities between Vuollerim and the embankments of fire-cracked stone becomes even more apparent when compared with the coastal site of Lillberget with its relatively large portion of typically Finnish and Russian components. The limited similarities between the quartz materials found on these two sites shows that they probably belonged to a common techno-territory in which the social relationships are practically absent (see Lundberg 1997:131).

Downstream Vuollerim and along the coast there are many newly discovered but unexplored sites. Some of these, like Lillberget, may belong to the Comb Ware Ceramic tradition, while others might have been utilized by the Vuollerim population as seasonal camps and/or by related groups as seasonal and/or base camps. It is therefore difficult to judge the degree and type of social contact that took place between these two different cultural groups solely from the limited comparison between Lillberget and Vuollerim; a comparison which indicates that contact was restricted. This presumed lack, or minimal amount, of contact might reflect that they belonged to different cultural traditions and/or social territories.

\section{THE LEGACY OF VUOLLERIM}

The excavations at Vuollerim resulted in more than just the discovery of a semi-subterranean dwelling from the Late Mesolithic period.

Lars Forsberg's work resulted in a doctoral dissertation which elaborated on the four theoretical models concerning the settlement patterns in Upper Norrland between $1500 \mathrm{BC}$ to $0 \mathrm{AD}$ (Forsberg 1985). This was the first archaeological dissertation which utilized archaeological materials from this area. Never again could one look upon Upper Norrland as a vast empty wasteland periodically traversed by mobile hunting groups on their way to some other place. By applying concepts previously developed by Broadbent (1979) for the northern coastal regions, Forsberg could present a description of different, complex and well organized prehistoric societies which had developed well thought out and elaborate subsistence strategies which were highly integrated with the prevailing ecological conditions in this part of northern inland Sweden.

The discovery of the semi-subterranean dwelling at Vuollerim quickly led to similar discoveries. The nationwide archaeological survey conducted by The Central Board of National Antiquities (Sw. Riksantikvarieämbetet) reached Upper Norrland in 1984 (Klang 1986:8). The Vuollerim site was used as a training ground where the first survey workers could familiarize themselves with this new type of feature. It was not long before similar types of remains were discovered and registered. Today there are many hundreds of similar sites known throughout the area, both singly or in larger concentrations which may well be the remains of whole villages (Klang 1987). The results from the excavations at Vuollerim and the following survey carried out by the The Central Board of National Antiquities gave us a whole new picture of this area and helped change the way we view the prehistory of northern Norrland.

The archaeological work also resulted in the establishment of a local museum in Vuollerim in 1991. This in turn created employment opportunities for the local people in an area which has otherwise been one of the most economically depressed regions in Sweden and which has recently suffered a steady decrease in both population and job opportunities.

But the archaeological investigations also resulted in something else, something which 
is rather unusual in Swedish archaeological circumstances. It infused into this rural northern Swedish community the idea of a long term historical perspective which gave the local people insight into their own time which both enhanced their own self esteem and gave them hope in the face of an ambiguous future. To really understand the effect this insight had on the local people one must know a little about Vuollerim's recent history.

The Vuollerim of today is a society that was created by the enormous economic forces which came to this area fifty years ago to exploit hydroelectricity. Not only were dams, power stations, high voltage lines, bridges and roads built. Whole villages were built up near the construction sites, with their own school, a post office, a town meeting hall and cinema, gas stations, shops, a medical station, laundries, mess halls, news stands, homes for the engineers and bureaucrats, housing for the working families and barracks for the unmarried workers. And when the work on one site was completed the whole village was dismantled, loaded onto trucks and transported to the next construction site where it was set up anew. It was a nomadic high technological community marching through the last European wilderness, an almost unbelievable enterprise, a social experiment in Swedish history which is unparalleled. This is a story which to a large extent has yet to be written, a history waiting for an historian. Today one can still see traces of these vanished communities. In the middle of a forest stands a lone street light, the foundations of the houses can be made out in the underbrush, the remains of a street which today leads nowhere.

When the dam and power station at Porsi was completed in 1962 the village of Vuollerim survived. The practice of moving the whole community was discontinued. Now the workers would commute on a weekly basis between their homes and the construction site. Work was plentiful and many decided to stay in Vuollerim. They borrowed money, bought or built their own houses, purchased their first TV or car and started a family. One can still detect the social structure that was established in Vuollerim at that time. Traces of the original farming community can be found to the south and west of the church. To the north and east lie the houses that were originally built for the power company's officials. Further eastwards one sees the houses built for the workers and even one or two of the mess halls and bachelors' barracks.

At the end of the 1970s most of the dams and power plants were nearing completion. Unemployment grew and in its wake many personal tragedies started to unfold. Bank loans and mortgages defaulted. People lost their homes, shops and businesses. Alcoholism spread; families broke apart and people started to move away. The history of these people seemed to both start and end with the beginning and completion of the exploitation of the water resources. For a community which in all appearances did not posses a history longer nor more enduring than that which was associated with the technological intervention it was difficult to build a future which seemingly had already ended.

The archaeological excavations at Vuollerim would have repercussions far outside the limits of the academic discipline itself. Suddenly this rural community was in possession of a history which not only reached at least 6000 years back into the past, but into Norrland's past. The archaeological discovery made people aware of a different perspective concerning their own conceptions about their own time and their own future. Other people and other societies had existed long before their own and had done so independently of the exploitation of the hydroelectric power resources. These other and different communities had developed, flourished and disappeared to be replaced by something else. This deep awareness with its long term historical perspective woke many to the possibility that Vuollerim's and Norrland's 
destiny was not solely dependent on anonymous powers from without. If this part of Sweden possessed a 6000 year old history then it might well have an equally long future. The decline which the present community was suffering from was not a permanent state, nor was it a natural condition. It was a short period in a long chain of transformations. This historical insight provided people with a new self awareness; that the potential for something new was already to be found within the region itself, in its own people, in themselves. Suddenly the community had both a past and a future, and the contents of that future were neither permanent nor predetermined. On the contrary, it could be modified and it could be transformed.

One of the most interesting results from the excavations at Vuollerim has never received any attention from archaeologists. It was not the discovery of the remains of a unique dwelling (it's hardly that). Neither was it because it was one of the most ancient sites found in the area (which it is far from being) and not because it was the first to be found. The really interesting result from the excavation was that it had repercussions far beyond archaeological circles; that it served as a catalyst and introduced a long term historical awareness and perspective on contemporary events and present day society. This happened independently of any apparent political agenda and for the most part beyond the boundaries of academic archaeology. A rural community awoke to the realization that history and prehistory are meaningful and that it could enrich their lives and understanding of both the past, present and future. This, I think, is the real legacy of Vuollerim.

Over 200 articles and 9 doctoral theses have been published in connection with the Lule River Research Project, some of which deal with different aspects of the river valley's recent history (see Baudou 1996 for references). But the fact remains that the archaeological work had a profound impact in ways which the other subjects involved in the project did not (Nordström 1989, 1991). Why? And how did the discovery in Vuollerim affect the Saami, the oldest known indigenous population of the area? Did it act as an integrating or segregating factor? Did it, or was it used, to further marginalise them and other minorities from mainstream Swedish society, either intentionally or unintentionally? Were there political intentions here that were not apparent in the beginning or of which I was not consciously aware of then?

These are sharp questions that need answering, but that would require a whole new article.

English revised by Laura Wrang.

ACKNOWLEDGEMENTS

$I$ wish to thank Evert Baudou and Noel Broadbent for their helpful comments, good suggestions and critical insights. 


\section{REFERENCES}

Baudou, E. 1992. Norrlands Forntid. Ett historiskt perspektiv.

- 1996. Luleälvsprojektet - att leva vid älven. In: Baudou, E. (Ed). Att leva vid älven. Atta forskare om människor och resurser $i$ Lule älvdal. Pp. 15-19.

Broadbent, N. 1979. Coastal Resources and Settlement Stability. A Critical Study of a Mesolithic Site Complex in Northern Sweden. Aun 3. Uppsala.

Falk, L. 1996. Historisk och förhistorisk kvartsbrytning i Norrland. In: Forsberg, L. (Ed). Arkeologi i Norr 6/7, 1993/1994. Pp. 59-100. Umeå.

Forsberg, L. 1985. Site Variability and Settlement Patterns. An analysis of the Hunter-Gatherer Settlement System in the Lule River Valley, $1500 B C-B C / A D$. Archaeology and Environment 5. Umeå.

- 1988. Bosättningsmönster vid Lule och Ume älv under bronsålder och förromersk järnålder. In: Arkeologi i norr 1. Pp. 51-101. Umeå.

Halén, O. 1992. Den kamkeramiska boplatsen Lillberget, Norra Sverige. Långväga östliga förbindelser i subarktis. In: Kontaktstencil 36. Pp. 73-99. Kaarina.

- 1994. Sedentariness During the Stone Age of Northern Sweden. Acta Archaeologica Lundensia. Series in 4:0. No. 20.

Helskog, K. 1984. The Younger Stone Age Settlements in Varanger, North Norway. In: Acta Borealia, volume 1. Pp. 39-70.

Klang, L. 1986. Ett nytt Norrbotten växer fram. Populär Arkeologi. Årg. 4, Nr. 2, 1986. Pp. 811. Lund.

- 1987. Den nya fornminnesinventeringen och den "nya" forntiden i Norrbottens kustkommuner.
In: Norrbotten. Norrbottens Museum Årsbok 1987. Pp. 32-58.

Loeffler, D. 1998. Arkeologisk Undersökning av Norpan 2 (J106A), Vuollerim, Raä 1292, Jokkmokks sn, Lappland, 1983-1987. UMARK 13, del 1-8. Umeå.

Loeffler, D. \& Westfal, U. 1985. A Well Preserved Stone Age Dwelling Site. Preliminary Presentation of the Investigations at Vuollerim, Lapland, Sweden. In: In Honorem Evert Baudou. Archaeology and Environment 4. Pp. 425-434. Umeå.

- 1986. En 6000-årig jägarbosättning. Populär Arkeologi. Årg 4, Nr. 2, 1986. Pp. 12-14. Lund.

Lundberg, A. 1997. Vinterbyar. Ett bandsamhälles territorier $i$ Norrlands inland 4500-2500 f.Kr. Studia Archaeologica Universitatis Umensis 8. Umeå.

Nordström, S. 1989. Kulturell identitet. Dess förändring förorsakad av arkeologisk verksamhet. Inledande studie av exemplet Vuollerim. Seminar paper (B:1) Etnologiska institutionen, Umeå universitet. Umeå.

- 1991. Kulturell identitet och arkeologi i Vuollerim. Seminar paper (C:1) Etnologiska institutionen, Umeå universitet. Umeå.

Wallin, J-E. 1986. Forntida Deltaformationer vid Lilla Luleälvs utlopp: En kartering gjord med hjälp av flygbildstolkning. Unpublished letter from Jan-Erik Wallin, Miljöhistoriska undersökningar HB, Umeå the 25th September 1986.

Westfal, U. 1987. Vuollerimundersökningarna. En arkeologisk och publik lägesrapport. In: Norrbotten. Norrbottens Museum Årsbok 1987. Pp. 24-31. 